\title{
Improvement measures to achieve sustainable construction labor performance
}

\author{
Saad Bin Saleem Ahmad \\ Department of Civil and Environmental Engineering, \\ Norwegian University of Sciences and Technology, Trondheim, Norway. \\ Email: saad.ahmad@ntnu.no \\ Tlf: +4796627996
}

\section{Muhammad Usman Mazhar}

Department of Management, Nottingham Business School, Nottingham Trent University, Nottingham, United Kingdom.

Email: muhammadusman.mazhar@ntu.ac.uk

\section{Ola Lædre}

Department of Civil and Environmental Engineering,

Norwegian University of Sciences and Technology, Trondheim, Norway. Email: ola.ladre@ntnu.no

\author{
Amund Bruland \\ Department of Civil and Environmental Engineering, \\ Norwegian University of Sciences and Technology, Trondheim, Norway. \\ Email: amund.bruland@ntnu.no
}

\section{Olav Torp}

Department of Civil and Environmental Engineering,

Norwegian University of Sciences and Technology, Trondheim, Norway.

Email: olav.torp@ntnu.no

\begin{abstract}
Construction industry is the largest industrial employer of the world. However, construction labor suffers from declining productivity, job satisfaction and wellbeing. Given its volume and labor extensiveness, measures undertaken to improve labor sustainability of the construction industry would have high impact for the future. To improve the sustainability of labor performance, this paper suggests decision-making measures at the strategic, tactical, and operational levels. Data is generated through targeted interviews of the top management of the five biggest Norwegian construction contractors. The measures suggested by the interviewees are analyzed and complemented with theory through a systematic literature review, resulting in the development of 45 measures to achieve sustainable labor performance at strategic, tactical, and operational decision-making levels. Due to strict labor laws and regulations, some frequently reported measures in literature do not hold relevance to the Norwegian construction industry. However, the quality of data and unique position of the Norwegian construction industry magnifies its relevance to the global construction industry.
\end{abstract}

\section{Keywords}

Sustainability; labor productivity; performance measurement.

\section{Introduction}

Construction is the largest and most fragmented industrial activity with significant impacts on sustainable development. It has significant carbon footprint through the use of material, construction processes and human capital. Alongside effective use of material, construction industry has persistently pursued the improvements on labor efficiency. One of the primary reasons in this pursuit has been the costs associated with labor. Labor costs account for 30-40\% of the total construction costs (McNally and Havers, 1967, McTague and Jergeas, 2002). Productivity is amongst the most important and influential basic variables governing economic production activity (Tangen, 2005, Singh et al., 2000). However, the construction labor productivity in the U.S. and European Union has steadily declined over the years (OECD, 2017b). Moreover, in relation to job type, job satisfaction and subjective wellbeing of labor, the construction sector is the worst performing industrial sector in the world (Helliwell et al., 2017). The declining productivity and lower job satisfaction among the construction labor is alarming for the policy-makers and top management in the construction sector. 
To minimize this impact, construction organizations are beginning to incorporate the idea of sustainability into their corporate culture by measuring performance against economic growth, environmental protection and social equity (Mirsky and Songer, 2009). "Sustainable development is the development that meets the needs of the present without compromising the ability of future generations to meet their own needs" (World Commission on Environment and Development, 1987, p. 37). Construction organization expresses the theme of sustainability through a wide range of design and construction approaches focused on economic growth and environmental protection. However, the theme of social equity is more often unrecognized or less focused upon and many sustainable initiatives end up in time and cost studies. The construction labor has economic, social and environmental impacts connected to the construction projects and its surrounding community which are largely unrecognized. It also stimulates the question whether construction organizations are putting enough effort to develop and sustain the labor at high performance from project to project.

The impact of construction labor in achieving the sustainable development goals is far too significant to be ignored due to many reasons. The foremost reason is that construction is the largest industrial employer of the world, with a combined workforce of more than 40 million in the EU, US and Japan (OECD, 2010). The European construction sector accounts for $7 \%$ of all European employment. In a broader perspective including the peripheral industries supporting the construction activities such as services, manufacturing and mining of construction products connects $12-15 \%$ of workforce to construction activity for the European countries. The decades long efforts by the European Commission have resulted in limited theoretical consensus on how to measure the wellbeing and sustainability (Stiglitz et al., 2009). Therefore, it justifies the approach of measuring wellbeing and sustainability of labor based on industrial sectors they operate.

This article seeks to align the sustainable development of construction labor through strategic, tactical and operational levels. This is because management of organizations involves decisions at strategic, tactical and operational levels. Strategic decisions are long term and high level to set future direction of an organization. The tactical decisions are medium term decisions and generally come after the strategic decision-making process. Operational decisions are short term and are day-to-day decisions (Misni and Lee, 2017). Given the number of construction industry employees, there lies a big opportunity for the construction companies to contribute towards their organizational and global sustainable development by measuring the Sustainable Labor Performance (SLP). The paper uses the term 'sustainable labor performance' and defines it as a function of economic, social and environmental development of labor. The SLP measurement system is proposed to enhance the project experience and wellbeing of construction labor, improve the environmental awareness of labor, and at the same time generate the economic value for the construction contractors. The paper investigates the following Research Questions (RQ) to come to the conclusions.

1. What are the strategic criteria for the measurement of sustainable construction labor performance?

2. How does the top management of contractors perceive the criteria of sustainable labor performance?

3. What are the tactical and operational measures to achieve sustainable construction labor performance?

\section{Methodology}

Theory has meaning when grounded in the philosophy. As PM revolution in mid 1990s was triggered by common adages like 'what gets measured gets done` (Kapłan and Norton, 1992), 'if you cannot measure it, you cannot manage it (Garvin, 1994) and (Halachmi, 2002) bridging it altogether 'if you cannot measure it you don't understand it; and if you cannot understand it you cannot control it; and if you cannot control it you cannot improve it. The knowledge building in PM suffers from the lack of solid theoretical foundations (Micheli and Mari, 2014). Solid theoretical foundation is intertwined with solid research philosophy. The theory in this study is built with a constructivist philosophical position and the knowledge is constructed through social constructivism with targeted interviews. According to Popper (1934), school of thought science progress with falsification of theories. Rather than taking the conventional approach of trying to limit the economic growth, reducing environmental impacts and providing green value to the end users, the intent of the SLP measurement is to create the foundations of construction organizational culture in which construction labor is so cohesively integrated in the sustainable cultural fabric that it requires minimum regulatory efforts.

The research design of this study follows a whole-to-part method, where a researcher starts with a wide research theme and narrows it down to more focused research questions through the course of study. The research flow diagram is presented in Figure 1. The research philosophy of this study aligns with the constructive school of thought, where knowledge is constructed through academic literature and social constructivism. To approach the 
RQs the study is divided into three stages of preliminary literature review, targeted interviews and systematic literature review. Each stage in this research study ends with providing an answer to the RQ. The RQ1 is reached with preliminary literature review, targeted interviews provide the answer to RQ2 and a systematic literature review answers the RQ3. Charmaz (2006) advocated to start with preliminary literature review about the research problem and refrain from the in-depth literature review prior to the data collection. The preliminary literature study reviews the performance measurement literature and develops improvement criteria at the strategic level for the sustainable labor performance measurement, which was then discussed and refined with experts' opinions prior to the interviews stage.

Preliminary literature review avoid obliviousness of the existing evidence (Lempert, 2007). The literature review based on the rationale of grounded theory research can help with identifying literature gaps, new approaches, providing justifications to background and framework of study, avoiding the mistakes of others, gaining critical knowledge and to stimulate thinking (Giles et al., 2013). The preliminary literature review in this study reviewed the performance measurement systems, models, frameworks and methods with the focus on labor sustainability issues, which provided justifications and theoretical background to answer RQ1. The widely practiced classification of the PM research is the project and organization level PM research. A limited number of PM researchers clearly associate their research to strategic, tactical or operational level PM. With the intent to develop the strategic criteria for measuring SLP to answer RQ1, the literature was explored with the boundary conditions of answer to two basic questions advocated by White (1996).

1. What will be measured? (Construction Labor)

2. Who will measure it? (Project and higher management)

Based on the results from the RQ1, interview questions were developed for targeted interviews. The improvement criteria at the strategic level was than discussed with the top management of the construction contractors in Norway. The interview guide provided in the Appendix A was used to construct the theory with social constructivism on labor performance and its sustainability. The interviews were conducted during SeptemberOctober 2017 in the Oslo region of Norway. Fifteen potential interviewees were contacted via emails in top Norwegian contractors to gain senior/top management level insights. However, five senior managers responded and agreed to be interviewed in this study, which is sufficient to produce findings as it is challenging to engage senior management personnel due to the nature of their job role. Each interview engagement was designed for one hour, where first 15 minutes were designated to introduction and a short presentation about the aims and scope of research study followed by a 45-minute interview session. All the interviews were conducted and recorded in Norwegian language and later transcribed into English. The improvement criteria to achieve SLP formed the core focus of the interviews. Social constructivism approach provided the liberty to the individuals to reflect on the world as they see it, while the researchers acknowledged their interpretations that are shaped by the personal experience and background adhering to the social constructivism lines advocated by Creswell et al. (2003). Rather than providing an indicator list to the interviewee's a blind indicator list referring to each interview question was maintained by the interviewers to steer the discussion. The study has a high relevance based on the sample size and the quality of data sample.

After gathering the perceptions of top management on the SLP, a systematic literature review embeds the perceptions in the theory. The RQ3 unearths the measures affecting the SLP with a systematic literature-based exploratory study. Labor performance measures were selected keeping in view the improvement criteria for sustainable development and the knowledge generated through interviews. The paper also presents the qualitative synthesis of the existing literature. The relevant research publications for the study were collected from a preliminary investigation carried out by adopting 'SCOPUS' 'Science Direct' and 'Google Scholar'. The keywords of 'labor performance' OR 'sustainable labor performance' were searched in titles with a key word 'construction' in abstracts. The exercise revealed 23 publications out of which most publications focused on analysing the impacts of different input variables on labor performance and had low relevance to aim of the study. In the context of construction industry, the search did not reveal a considerable set of relevant publications. Most of the relevant literature was captured under the domain of construction labor productivity with the thread of 'labor + productivity' AND 'construction + industry' OR 'construction + sector' AND 'factor' OR 'indicator'.

The search thread revealed 308 publications with source types including books, conference papers and journal articles. However, for this study 206 research publications from the peer reviewed journals were filtered out for further analysis. For all the search hits, authors carefully went through the titles and abstracts. The articles in which the respective authors attempted to identify or rate the factors influencing the construction labor were examined 
closely to keep the relevance with the research goals intact. With a more through screening 34 peer reviewed articles were selected for the study. In depth study of these articles revealed that the search engines failed to capture some of the relevant studies, such studies were than collected with the reference tracking from the selected articles and grouped into a peripheral study set. The initial set consisted of 34 articles which surged to 55 articles after reference tracking.

\section{Performance Measurement}

The importance of identifying an organization`s performance is evident throughout the global markets (Yang et al., 2010). Performance Measurement (PM) at the organizational level (strategic) in construction has traditionally relied on efficiency and return on capital, which have been criticized as narrow, reactive, and mostly financial (Bassioni et al., 2004). This is due to the focus of measurements on easily quantifiable factors such as cost and productivity. However, given the dismal state of construction industry, the researchers have been emphasizing to assess performance beyond the easily quantifiable financial measures (Latham, 1994, Egan, 1998). According to Neely et al. (2005), PM is 'the process of quantifying effectiveness and efficiency of actions', where performance measure is the parameter used to quantify efficiency and/or effectiveness of actions (Neely et al., 2005). However, the temporary nature of project teams and construction sites makes standard industrial PM tools impractical for construction (Navon and Sacks, 2007).

The most widely practiced PM frameworks in construction organizations include: Performance Matrix, Worldclass manufacturing (WCM), Performance pyramid, The Balanced Score Card and the Performance Prism. Keegan et al. (1989) performance matrix categorized performance measures into cost, non-cost measures and external, internal measures. However, the non-cost internal performance measures only include design cycle time, on-time delivery, first-pass quality, number of new products and product complexity. No measure reflect the wellbeing and development of labor. Maskell (1991) world class manufacturing suggested measures such as quality, time, process and flexibility to map performance. Cross and Lynch (1988) presented the performance pyramid based on a performance criterion and its underlying relationships to sustain success for the organizations.

The most extensively used performance framework is the Balanced Score Card. Kaplan and Nortan (1992) introduced the four perspectives of financial, customer, internal process, and innovation in a framework called Balanced Score Card. Although Balanced Score Card is an excellent contribution to the subject of PM. It has been reported to fail (Neely and Bourne, 2000), and like the other PM frameworks do not reflect and incorporate the perspective of labor. The performance prism of Neely and Adams (2001) suggested a different approach to PM. The performance prism challenged the approach that PM should be derived from the strategy and advocated that PM should first concentrate on the measurement of stakeholder needs and then on the strategies, processes and capabilities. Process measures based on stakeholders needs distant the top management form the construction labor. Whereas it's the human interventions that generate value in the construction process, improving the outputs and quality of human interventions can provide better performance criteria to sustain success.

Alongside performance frameworks, performance models have gained popularity to improve the organizational performance. The most popular performance models are the European Foundation for Quality Management $(\mathrm{EFQM})$ in Europe, the Malcolm Baldrige National Quality Award (MBNQA) in the United States, and the Deming Prize in Japan. However, the basic concern with the performance models is that they only concentrate on a certain aspect of performance such as EFQM, MBNQA and Deming prize refer to quality management for improvement in performance. Bassioni et al. (2004) indicated that these performance models are grounded into the concept of total quality management (TQM). Other limitations associated with the performance models are limited performance criteria, and the inability to develop a relationship between the performance criteria to simulate real life complexities. The EFQM does incorporate the people's dimension in performance criteria, but it does not establish the measures to evaluate or assess the people's development and wellbeing.

Key performance indicators (KPI) is the most robust method used for PM. Construction organizations have largely adopted the KPI approach and most of the literature on organizational performance revolves around it. Organizations measure performance with different intents and accumulate information with KPIs. However, aggregation of the KPIs to reflect a specific intent has been problematic (Horta et al., 2009). Beatham et al. (2004) refers to KPIs from KPI programs as post event and lagging indicator. Lagging indicators have limited use and does not support the top management to intervene in time on projects to align them with organizational performance perspectives if they are drifting from the course. 
Several KPI programs were launched across the world include (Egan, 1998, Pillai et al., 2002, Cheung et al., 2004, Rankin et al., 2008, Kim and Huynh, 2008, Skibniewski and Ghosh, 2009, Shamas-ur-Rehman Toor, 2010). As performance is a relative phenomenon, several national benchmarking initiatives to compare cross-organizational performance also gained popularity. Some of the prominent benchmarking initiatives include:

1. Asian Productivity Organization (APO) Productivity Data-book Project, Japan

2. Construction Industry Institute (CII) Benchmarking \& Metrics (BM\&M), US

3. Construction Excellence (CE), UK

4. Performance Measurement for Benchmarking in the Brazilian Construction Industry (SISIND-NET Project)

5. National Benchmarking System (NBS), Chile

6. Danish Construction Institute (DCB), Denmark

7. European Construction Institute (ECI) Benchmarking Initiative, UK

The literature on performance frameworks, systems, KPIs and benchmarking initiatives reflects gaps and limitations in capturing the wider spectrum of labor development and wellbeing. Although performance initiatives recognize the internal processes and people as performance dimensions it is more often reflected in a productivity perspective. The literature investigation suggests that construction labor do not get the required attention in relation to its impact in developing a sustainable future. Ahmad et al. (2018) also argue that although construction is one of the largest sectors that drive the global economy, yet it has failed to receive the necessary attention.

\section{Developing sustainable labor performance criteria}

Sustainability has developed as a unanimous solution to addressing a vast array of business problems from work rights, consumer protection, environment, corporate governance, and reaching to the impact of business on broader social issues, all put together in a relationship of balance to generate profit (Savitz, 2013). In an attempt to quantify sustainability, Jhon Elkington (1994) proposed a PM framework called 'triple bottom line'. This accounting framework went beyond the traditional measures of profits, returns on investment and shareholder value and incorporated social and environmental dimensions. The triple bottom line framework measures performance based on the three dimensions of financial, social and environment. These dimensions of performance are referred to as 3Ps of profit, people and planet. According to Savitz (2013):

\section{'Triple bottom line captures the essence of sustainability by measuring the impact of an organization's activities on the world'.}

To develop Sustainable Labor Performance (SLP) criteria, the point of origin is to capture the 3Ps of profit, people and planet associated with the construction labor. Adhering to the suggested methods of measuring sustainability by several academics (Elkington, 1994, Savitz, 2013, Hall, 2011). The triple bottom line, 3Ps or economy, social and environmental dimensions of construction labor serves as the foundation stone of the SLP. The next stage was to develop a set of criteria that can reflect the economic, social and environmental dimensions of construction labor. McDonough and Braungart (2002) presented a framework (see Figure 2) called 'fractal triangle' to develop triple bottom line measurement dimensions to reflect to sustainability. To approach the second stage of SLP criteria the 'fractal triangle' is used to raise the labor sustainability issues.

The fractal triangle embodies nine triangles, the extreme corners represent the economic, social and environmental dimensions. The application of fractal triangle begins with the lower-right corner which represents the economy. The perspective in this triangle is purely economic which raises the concern of generating more profits from labor. Moving from economic to economic-social dimension, the social side of labor is reflected wearing the economic shoes. The concerns are of profits and profitability by improving the competence of labor in this dimension. The social-economy dimension observes the economy from a social lens. The focus here shifts more towards fairness in wage distribution and social rights. Moving towards the social corner of the fractal triangle the focus shifts to the pure social side of labor and we raise questions such as quality of life and project experience of labor.

The social-environmental position explores the social construct of labor that contributes towards better organizational environment, which brings health, safety and wellbeing of labor into concern. In environmentalsocial stand-point the focus changes to investigation of the labor attributes that contribute towards a better project site environment, here the labors respect and awareness of the project surroundings comes into focus. The pure 
environmental corner explores how labor as tools of nature contributes towards a better global environment, which shifts the focus to labor's contributions in reducing construction waste from project sites. Continuing to the environmental-economy triangle, economy comes into picture again and focus orients at more effective or minimum use of organizational resources. The economy-environmental coordinal position aims to target environmental goals from the economic instruments such as labor. Higher efficiency of labor operations reduces costs and unnecessary human interventions further reducing the waste. Based on the fractal triangle presented in Figure 2, nine improvement areas are indicated below which a construction organization should improve to achieve the SLP;

1. The profits and profitability of labor should improve (Economy)

2. The competence of labor should improve (Economy-Social)

3. Labor should have improved wage distribution and social rights (Social-Economy)

4. Quality of life of labor and project experience should improve (Social)

5. The health safety and wellbeing of labor should improve (Social-Environmental)

6. Labor respect for surrounding community and nature should improve (Environmental-Social)

7. Labor contribution in reducing construction waste should improve (Environmental)

8. Labor should improve on using resources more effectively. (Environmental-Economy)

9. The efficiency of labor should improve. (Economy-Environmental)

\section{Top management perception of Sustainable Labor Performance Criteria}

The SLP criteria was discussed in the targeted interviews with the top management of the Norwegian contractors to gain the current perspectives of the Norwegian construction industry. Table 1 presents job designation and experience of the interviewees in the Norwegian construction industry, it further reflects the number of employees and annual turnover of the contractor. Norwegian construction industry in total employees 234788 construction workers (Statistics Norway, 2018). The top management interviewed for this study represents 15853 workers, which makes $6.75 \%$ of total Norwegian construction employment. In terms of turnover the selected contractors have $11.54 \%$ of the total Norwegian construction market share. Furthermore, the selected contractors are among the Norwegian top 10 contractors and engage a lot of sub-contractors which are not reflected directly in their employment but are affected by their respective sub-contractor labor policies.

It is important to note that the performance and productivity drive of the mid 1990's also influenced Norwegian construction industry, and the construction contractors interviewed revealed that in the earlier days (mid 1990s) they had the measurement drive where a lot of things were being manually measured all the time on the construction sites. Some Norwegian contractors even had specialized measurement department with the sole responsibility to measure different aspects of the projects. However, most of the measurements were unnecessary and required a lot of effort and resources. The contractors have now dropped most of the unnecessary measures and are trying to focus and standardize the important measures. The information and data collected with the measurement drives is still valid and formulate the contractor's experience. The experience from measurements is a vital source for contractor's planning and estimations. The section below summaries the views of interviewed participants within the nine improvement dimensions raised in the SLP criteria.

\subsection{Profits and profitability}

Measuring profits from the labor it is not a common practice of Norwegian contractors. The detail measures such as net-profit per actual hours worked or return on asserts per worker are not usually measured for a project. The Norwegian contractors engaged in the interviews termed these measures of little use, presenting an argument that the hourly labor cost for different types of construction works is standardized by the Norwegian organizations in an Akkord system. The system defines as performing of certain task of construction work for a certain amount. It corresponds to an hourly wage, where the employee is paid per hour. Moreover, the hourly cost is a collective agreement between the labor and the contractor, where the labor cost for a particular construction work is discussed between the labor representative and the contractor's project manager before going into the project. 
In most of the construction projects the prime contractors engage the sub-contractors. When a sub-contractor is engaged the only measure that enters the log book of prime contractor is the cost. In such a case measure like return on assert per worker will lose its credibility. The profits are only measured from the planned costs and actual costs incurred in the project. The project managers usually track cost on a lower frequency than the working hour reports. However, no bells are rung if everything goes to the plan.

The Norwegian contractors at times do track the labor cost per square meter of built area. However, it has more relevance for the roads and tunneling projects, where it is measured as cost per meter. Construction projects are hardly similar and several factors that determine the final labor cost per square meter of built area are never the same. Profitability is an issue which Norwegian contactors reflect with a different approach, and the context of Norwegian construction industry is of high importance to understand that. The Norwegian construction industry is governed by strict labor laws. The market is also short of skilled labor and contractors need to be attractive and offer more than the government requires them to interest the skilled labor. This in turn results in higher costs for contractors.

\subsection{Competency of labor}

The Norwegian contractors are well aware of the issues such as capacity of labor, ageing work force and absentisme. To cope with such challenges almost all the big contractors have internal schools and training programs for the young labor in the industry. The training programs provide the young labor and professionals to develop their skill and competency to the industry demands. The companies interviewed had young labor and professional programs that compete with each other to attract the young blood. Moreover, contractors are egger to develop a culture that decrease the absentisme and promotes the learning at the work place.

\subsection{Fair wage distribution, and social rights}

Due to strict Norwegian labor laws the contractors do not have much choice here. The labor unions in Norway publish a yearly wage graphs in relation to the type of work, experience and education. The wages are revised every year with a through a collective agreement between the labor unions, employee's representative groups and the employer. The wage graphs are made public so that employees can relate their experience and education to the yearly graph and see if they lie on average, below or above the average in terms of salary for the construction professionals. Whereas the Akkord system for the labor is update for hourly rate of labor works every second year.

The shortage of skilled labor in the Norwegian construction industry motivates the construction companies to do better than the minimum wage requirements and social rights. All the companies interviewed where vocal in the reflecting that they have higher wages and better pension plans as compared to their competitors. Although it is a general practice among the Norwegian construction contractors, the representatives from the company 3 and company 4 particularly mentioned that their human resource department benchmarks the wage distribution and social rights in their company. The human resource department have their own internal employee surveys, and if they indicate an area where the company is lagging, the issue is taken up with the higher management and an action plan is created and followed up. The action plans usually consist of educational courses both internal and external.

The company 3 and 4 also indicated the challenge with the expanding European Union open market for labor when it comes to profitability and fairness. The representative from company 4 further reflected that there are two types of workers coming from the different European countries in Norway. The ones who settle in Norway and the ones who travel back and forth for work assignments and do not settle in Norway. The ones who settle require the same salary as experienced and trained Norwegians, most of them do not speak Norwegian or English. The ones who don't settle are willing to work on a significantly lower salary, as cost of living in their home country is significantly lower than living in Norway. Therefore, this has created a bit of imbalance in the Norwegian construction market when it comes to fare wage distribution and social rights. Furthermore, it is now harder to attract the young Norwegians for construction labor.

As all the companies interviewed are big contractors they have internal development programs that provide equal development opportunities to the employees for where the employees can plan for and target future promotions within the Norwegian construction industry. There are no standardized measures for the wage distribution and social rights. However, it is steered through in collaboration with the unions, employees, human resource department and company through yearly reports and development programs. The transparency of the internal system and collective agreements keeps the companies' system in check. Moreover, company 3 mentioned that it is necessary for all the employees to take courses in racism and such issues to avoid them. 


\subsection{Quality of life and project experience}

The quality of life and project experience of the labor is assessed from employee interviews and surveys. Most of the companies interviewed practiced an annual one-on-one employee interview with the immediate leader in the company. However, a company 2 reported that the frequency of their one-on-one interviews is every $3^{\text {rd }}$ year. The needs of the workers and issues related to the quality of life, work pressure, relationship with colleagues, physiological work environment is discussed in detail in the interviews. However, given the low frequency of employee interviews it fails to capture the project-based experience and sentiments of the labor. Although the employee interviews and surveys are kept anonymous, the representative from company 3 mentioned that it is very often that the people are not daring to say and speak up the important things.

The interviewee from company 1 stated that quality of life and project experience is achieved with good management process. The philosophy is to develop a culture within the organization that people talk to each, which is the best way of knowledge transfer. Furthermore, the quality of life is approached with providing the labor with sports opportunities, which may also help in building an interactive culture.

The management meetings on the projects in the companies do provide a feedback and experienced is transferred in the end. However, the focus of these meetings remains on the comparison of pre-project calculations to the actual time and cost used for project delivery. The Norwegian contractors do not concentrate on gathering individual experiences, and the project learning is basically learning through planning. All the contractors interviewed have already developed internal systems for planning, start up and experience transfer. However, if everything goes to plan no fingers are pointed and no bells are rung.

\subsection{Health, Safety and Wellbeing}

All the Norwegian contractors interviewed for this study gave a high importance to health, safety and wellbeing of the labor. The general practice is to categorize the accidents, injuries and near misses, and sick leave with an established internal reporting system. The representative from company 4 described that health and safety is the agenda on every weekly meeting where the work for the whole week is scheduled. The health and safety work is also planned and briefing are provided to the labor in case of a special requirements. The professional workers are provided with a template to follow and they should ensure the safety of their work. In the routine practices 5 minutes are provided to the workers every morning to discuss the special health and safety needs for the daily work in process. Moreover, every laborer has the opportunity to report the health and safety hazard to the corporate health service of the company at all times during the project.

The companies maintain statistics on the health and safety issues and the focus is on achieving zero tolerance in terms of health and safety issues. The wellbeing of labor is brought up in the employee interviews and surveys. However, the sub-contracted labor is not a party to the employee interviews and surveys.

\subsection{Labor awareness of surrounding community}

All of the interviewees termed it as a project specific issue, where every project has different surrounding conditions. For the construction sites in proximity of schools and hospitals the permissible construction noise levels are low and strictly time dependent. The representative from the company 1 mentioned that they measure it with the satisfaction of the surrounding community, by analyzing the project site in advance and informing the neighbors and surrounding community upfront of the working routines. All the Norwegian contractors need to adhere by the project specific guidelines on running the construction site in relation to the surrounding communities. There are certain things that were highlighted by the representatives of company 4 that might not be on the construction sites guidelines, but the project administration must consider such as when setting the lightings on the projects sites they should not light on to people and their homes.

Although it was termed as a planning and management issue where the work should be planned to cause minimum disturbance to the surrounding community. Company 3 mentioned that it is the labor equipment also pollutes the environment, and labor is free to choose the tools they want to use for work. Although it has not been the goal of the company 3 , they continuously focus on keeping the tools and equipment up to date so that at least the emissions and noise could be reduced.

The representatives from the company 3 and 4 were also of the view that the awareness of the surrounding community in term of labor is a personal issue. However, it is necessary for all new employees to go through extensive introduction courses where the project site issues are introduced in detail. It is upon the individual to 
what extent they follow up the rules regarding the surrounding community. Following up all the rules and putting in extra effort towards the surrounding community have its toll on the working hours of the job.

An important massage company 3 and 4 trying to convey here was that the Norwegian construction industry has changed over the years. It has a lot of European immigrant workers that primarily come here to earn money. Furthermore, the company 3 mentioned that it is for sure that the local labor feels greater responsibility for the environment and surrounding community because they live in this community, whereas the immigrant workers temporarily coming here for certain task do not feel that responsibility towards the community.

This is also the negative effect of the labor incentive programs such as the Akkord system that all the Norwegian contractors' practice. The focus of the labor remains on completing the work task in minimum amount of time to get the maximum bonus payments, as it is connected to the working hours. In such a time strained setting the issues like awareness of surrounding communities and reducing construction waste have higher probability to be ignored by the labor. There are no measures in place to assess the labor awareness of surrounding community, it is followed up through management guidelines, and if no one complains from the surrounding community the things are assumed to be in order.

\subsection{Construction Waste}

The Norwegian construction companies have put a lot of effort in reducing the construction waste, especially with the help of ICT tools such as Building Information Modelling (BIM). However, it still is a concern which requires a collective effort. In the interviews we got very contrasting views on the construction waste. The representative from the company 1 was more concerned about the time waste than the material waste on the construction site, maintaining that the material cost in relation to the time cost is very low. Company 4 also maintained the stance that the tools and buying new material is not as expensive. However, there is still a huge potential to reduce the material wastes. Company 2 reported that it is a focus of their strategy to reduce the construction material waste and mentioned that their traditional practice of measuring the construction waste has been through the waste sorting. Furthermore, recommended that the waste quantities in kilograms may provide a better insight.

The companies also mentioned that the construction client have a lot of influence on the construction waste. Some clients are more concerned about the environment and the use of fossil fuels and water on the projects. Company 2 also mentioned that they are on their way to reach fossil-free construction sites on some projects.

On the individual level reducing construction waste depends upon the worker. The representatives from the company 3 and 4 were of the view that the trends on the construction sites have changed and majority of workers do not think about reducing waste and conserving material for future use, as things have become easier and cheaper to buy. Company 4 further elaborated that in old days in Norway before the open European markets the workers used to think all the time that if they have something left on the project (eg. a pack of nails or a plank) where can they use it in the future. So, material and things were being used to a greater degree. However, now the general attitude of the workers is to waste the material as it is not coming out of their pockets.

\subsection{Effectiveness}

It was hard for most of the participants to clearly distinct the concept of effectiveness with that of efficiency. The issue can be largely due to the terminologies in the Norwegian language. Apart from the representative of company 2 , all the participants were of the view that it is only the effectiveness of the planning they relate to and focus on. However, given the open-ended nature of the interviews it can be deduced that the Norwegian contractors target the effectiveness issues with co-management and collaborative planning. That is line with the drive of lean construction in the industry. Effectiveness goals are reached with involvement of all the stakeholders in the project, which set the course of the project on the right track with all the parties involved. Company 2 highlighted that on some projects they measure the errors of quality and error rates. However, the industry lacks an aggregation system for such measures. The effectiveness on the individual scale is not measured, it is just followed up.

\subsection{Efficiency}

The building projects are very different from each other and a number of project input factors change from project to project. However, general output measure for the Norwegian contractors on the building projects is production per square meter, and for the infrastructure projects is production per meter of tunnel or road. The efficiency measures also differ among the project tasks such as for groundworks is cubic meter per hour. The intent of efficiency measures for the interviews was largely for internal calculations and forecasting. 
The Norwegian construction heavily bank on the Akkord system for measuring the labor efficiency and also relate it as an efficiency improvement system. A construction plan is developed based on the contractors past experience and efficiency is measured in terms of achieving the plan.

\section{Systematic literature review on factors affecting labor}

This section explores the factors affecting labor and classifies them in the decision-making levels in an organization: the strategic, the tactical and the operational. Performance and sustainability initiatives can fail due to the lack of clear distinction between the strategic, tactical and operational decision making. In the context of Norwegian construction industry corporate management, divisional heads, and project directors are responsible of strategic decision making. Project managers take the tactical decisions, whereas the site manager is responsible for the operational decision making about the factors affecting labor. The decision-making classification is maintained throughout the literature review and the results are presented in Table 2.

Construction labor productivity is a well-discussed topic of interest for academics and practitioners. Dolage and Chan (2013) established from a literature review that the highest percentage productivity literature is devoted to construction LP. Plethora of researchers (Thomas et al., 1990, Rojas and Aramvareekul, 2003, Abdul Kadir et al., 2005, Dai et al., 2009) have indicated numerous factors that influence construction LP. For the collection and ranking of these factors, researchers have widely opted for the questionnaire surveys and interviews with construction practitioners.

The depreciation in LP is usually attributed to multiple factors rather than a single one, which might be interdependent on each other. Some factors have the possibility of control such as factors related to construction materials and managerial practices, whereas some factor is mutually exclusive and cannot be controlled such as extreme weather conditions. Nevertheless, it is the belief of academics and practitioners that a majority of factors affecting construction labor productivity can be improved (Rojas and Aramvareekul, 2003, Dai et al., 2009). Therefore, an extensive research is published on identification and prioritization of the factors from the managerial standpoint (Rojas and Aramvareekul, 2003, Ghoddousi et al., 2015, Jarkas et al., 2015, Mahamid, 2013).

Rojas and Aramvareekul (2003) inferred from a survey targeted at the potential drivers of construction LP that productivity is a state of mind and that can be controlled through management, whereas construction industry's environment and external conditions have a far less influence than anticipated by the academics. According to Rojas and Aramvareekul (2003), the greatest opportunity in improving construction productivity lies with improving methods, training programs, workers' motivation, strategic and procurement management. Durdyev and Mbachu (2011) also concluded with their analysis on New Zealand's construction industry that internal factors contribute far more to LP than the external factors that are beyond the management's control.

Thomas et al. (1990) grouped the LP factors under six categories of: manpower-labor, design features-work content, environmental-site conditions, management practices-control, construction methods, and project organization structure. Abdul Kadir et al. (2005) used a questionnaire survey to rank the most influential factors that affect the LP in the Malaysian residential projects. Enshassi et al. (2007) identified 45 factors that negatively influence LP in the Gaza strip and grouped them in the ranking order of: material/ tool factors, supervision factors, leadership factors, quality factors, time factors, manpower factors, project factors, external factors, motivation factors and safety factors.

The existing most wide-ranging and detail study on factors affecting construction LP in the U.S. was carried out by Dai et al. (2009), where they identified 83 factors and grouped them under eleven categories: supervisor direction, communication, safety, tools and consumables, materials, engineering drawing management, labor, foreman, superintendent, project management and construction equipment. Dai et al. (2009) surveyed 1996 crafts workers on 28 U.S. industrial projects to identify 10 most critical and influential LP factors, and further established a relationship amongst these factors. The different perceptions of LP between the generations of craft workers (Dai and Goodrum, 2012), foreman and craft workers (Dai et al., 2007), the English and Spanish speaking craft workers (Dai and Goodrum, 2011a), union and non-union craft workers (Dai et al., 2009) were explored with a survey and a significant differences amongst the compared groups was reported.

Jarkas and Bitar (2011) spearheaded the labor productivity research in the Middle-East (Kuwait, Qatar, Oman and Bahrain). Jarkas and Bitar (2011) identified 45 factors and grouped those under four categories: technological, human/labor, management, and external. A targeted questionnaire survey with 157 respondents from construction firms in Kuwait established the relative importance of the 45 factors and 4 groups amongst the construction practitioners in Kuwait (Jarkas and Bitar, 2011). Jarkas and Younes (2014) also identified 43 factors contributing 
towards the construction delays in Qatar and categorized them into factors related to employer, consultant, contractor and external factors. A similar type of study was conducted for the construction firms in Oman and Bahrain (Jarkas et al., 2015, Jarkas, 2015, Jarkas and Younes, 2014), where LP factors were identified and classified into management, technological, labor and external factors.

Khahro et al. (2016) investigated the variables impacting on the LP of the construction industry in Pakistan, and reported the following crucial factor groups: human factors, labor motivational factors, inappropriate supervision, leadership, material/tools, time, safety, quality, project management and external factors. Naoum (2016), with a literature review, interviews and a questionnaire survey aimed at identifying and prioritizing the factors bearing impacts on LP in the UK construction industry, and clustered them into factors related with pre-construction, during construction, organizational and motivational and social factors.

Pilateris and McCabe (2003) advocated for four input measures (i.e., accounts receivable, fixed asserts, total debts, and indirect expenses) and four output measures (i.e, working capital, tangible net worth, net income and sales) for contractor's financial evaluation. El-Mashaleh et al. (2007) opted for metrics approach with two inputs (safety expenses and project management expenses) and five outputs (cost, schedule, profit, customer satisfaction and safety) to benchmark construction firm's performance. Horta et al. (2012) used four performance measures (i.e, profitability, value-added, financial autonomy and liquidity) for measuring financial performance of construction companies.

Literature acknowledges the factors affecting labor may vary from country to country. The perceptions of LP can be different among different groups possibly within the same construction site (Dai and Goodrum, 2011b, Dai et al., 2007, Dai and Goodrum, 2011a). Despite the extensive research, generalizations and standardizations on common LP factors are yet to be achieved (Panas and Pantouvakis, 2010). The literature reveals that most of the research on factors affecting LP is centric towards the operational level where most of researchers have given the due importance to wellbeing factors of labor to improve productivity with job satisfaction and motivation. Furthermore, literature reflects a high frequency of managerial, technological, material and equipment factors for improving LP.

\section{Results and discussion}

Sustainability has begun to impact both the long term and everyday practices of the leading construction companies of the world. Minimizing the impact of construction projects might slow down the environmental destruction, an efficient use of construction resources might help the construction organizations survive for a few more years. But these are the minimum conditions of sustainability for mere survival of the organizations (McDonough and Braungart, 2002), and that might be the reason projects and organizations still fail. In order to part ways from the negative effects management of construction labor, the SLP system highlights the positive aspects of the construction labor. The insights from the output based positive measurement system are more insightful and reliable than the system based on the agenda of using less material to construct a project and measuring its performance against the minimum sustainable criteria.

The desktop study on construction labor revealed that it lacks behind other industries such as manufacturing, both in terms of productivity and wellbeing of workers (Helliwell et al., 2017). Social and economic progress complements each other and over the last many years, researchers have reported substantial relations between the two (Ostroff, 1992, Schneider et al., 2003, Patterson et al., 2004). But the struggle lies in measuring sustainability, as the 3Ps don't have a common unit of measurement (Hall, 2011). The profits are measured in currency, but what units can be used to measure the social capital, health and environment. One solution is to monetize all the dimensions of 3Ps and place financial values on social and environmental goals. The sustainable practices that originated from such perspectives largely revolve around the resource efficiency in the construction processes and the initiatives for the end users to meet sustainability by minimizing the impacts of the construction projects. McDonough and Braungart (2002) infer that these sustainable practices are the strategies for managing negative effects, build on the agenda of being 'less bad' and hardly provide an inspiring prospect. It might well be a possibility that construction organizations might be placing so much effort into resource efficiency and reducing the negative impacts of projects that they might be losing the real value.

The RQ1 was answered with presenting nine improvement criteria to achieve SLP. The nine improvement criterion are suggested to improve the economic, social, and environmental progress of construction labor to sustain the labor performance of a contractor. Each construction contractor is unique and operates in a unique setting achieving consensus over outcome measures such as improvements seems a higher probability. Such methodological 
approach of measuring improvements for national performance beyond the production economics theory has been advocated in the book 'Beyond GDP' (Fleurbaey and Blanchet, 2013). The importance of a composite approach (subjective and objective) output measures is also highlighted with the Human Development index and OECD Better Life index, where the subjective output measures such as happiness and satisfaction adjusts the economic measures for the performance on social outcomes (Stern et al., 2015). The output-oriented nine improvement criteria were discussed with the top management of Norwegian contractors to formulate the respective perceptions to reach the answer of RQ2.

In a highly fragmented industry as construction, where the nature of firms may differ from public to private, project type (house, apartment, road, bridge etc.), project environment and contract types differ, construction methods and practices might also differ, let alone the perceptions about LP amongst the workforce. Achieving consensus over standardized inputs seems like a near impossible task for construction industry. In such a setting where a consistent and reliable data generation remains an issue, the outcome indices may provide a more standardized and reliable data generation for future benchmarking practices (Fleurbaey and Blanchet, 2013). A wide problem such as LP in a highly fragmented industry as construction demands a composite approach to the problem. A subjective and objective measurement approach to LP was reflected by all the interview participants. Moreover, the agreement on nine improvement criteria at the strategic level achieved unanimous acceptance.

The systematic literature review on the factors affecting labor performance after developing and collecting top management perceptions on SLP resulted in 45 extensive measures presented in Table 2. The selected measures are grounded in the theory based on the sustainability measurement. The measures are divided into strategic, tactical and operational levels. The extensive list provides the contractors with improvement measures from where they can choose the measures that best serve their respective purpose. The selected blend of measures represents objective as well as subjective measures. The objective measures are the quantitative measures from where the contractors can objectify the future growth on labor development; whereas the subjective measures inquire the subjective social and environmental state of labor. The characteristics of subjective measures are that they are not linked to any definite objective, rather they are inherently relative (March and Sutton, 1997). The social dimensions of labor performance are suggested from the subjective labor perception, keeping in view the measurement of social progress of a nation by Stern et al. (2015). An alignment is maintained through the measures selection process to improve the national sustainable growth.

The economic progress is evaluated with the improvements in profits and profitability of labor. Rognlie (2016) inferred from the producers (contractors) perspective that gross measures such as gross value added, and gross capital measures are more appropriate and provide a better reflection of the structure of the production (construction) process. The debate over the use of actual hours worked or number of persons employed is still active in the LP measurement literature, and productivity results differ when using working hours or head-count data (OECD, 2017a). However, actual worked hours data provide a much more refined measure as compared to head-count data, as it captures the total working hours of all the labor engaged in the construction process and accounts for the overtime, self-employed and rented labor. Moreover, the labor costs relative to volume (total project cost) of output is a broad measure and reflect the labor competitiveness of the firm (contractor) within a country (OECD, 2017b). The percentage change in the labor costs to the total cost of construction reflects the change in efficiency of labor utilization and can be reflected on a quarterly time line.

The combined social and environmental progress will lead to reduction in the labor cost, further leading towards the economic progress. Social progress of the labor will impact the productivity of the labor, the environmental measures will increase the labor awareness about reducing construction waste and working more effectively. Construction LP at the national level is measured as gross and net domestic product per hours worked (OECD, 2017a). The economic measures map the labor economic progress to establish its relationship with the social and environmental progress of labor.

The social measures assess the labor's quality of life and project experience. It indirectly reflects the management's mantle and resolve to provide for its workers with the basic structure of wellbeing to sustain the construction operations. Are the workers able to achieve satisfaction from the job, obtain information (site orientation, trainings and workshops) regarding the job, maintain a healthy and safe working environment, communicate grievances and contribute with learnings for future improvements, and the availability of welfare system to ensure healthy and prolonged life. The workers motivation assesses the organization's ability to motivate the workers. 'Motivation is the driving force that physiologically and psychologically stimulates an individual to fulfil goals, needs and 
expectations' (Lam and Tang, 2003). The workers motivational factors assess the worker motivation for the future projects.

The environmental measures are intended to promote a culture among the labor to identify and perceive construction waste. Identification is the first step in reduction of any waste. Productivity waste is any waste related to construction materials, machinery, transportation, labor etc. at the construction site. Whereas environmental progress measures of labor are the worker's perceptions of wasted opportunities on the project to reduce the construction waste. Waste is the term in lean production that is used for the 'non-value adding costs' (Buzby et al., 2002). 'Waste is defined as activity, which absorb resources but creates no value' (Womack and Jones, 1996). The environmental measures reflect upon the labor perception of wasted opportunities around them for more effective use of resources. Environmental measures are suggested form the stand point of measuring the progress on the lean perspective of the labor i.e., to minimize the construction waste with every cycle. Koskela (2000) inferred that it is essential for continuous improvement in lean construction that a system capable of measuring waste inherent to the process is in place. Labor is at the work face of the construction process and workers perception of amount of waste can indicate the margin of improvement and reflect the project management competency in reducing the construction waste. Therefore, it may catalyze the management to improve internal management strategies to reduce the construction waste and contribute towards the growth in environmental awareness.

\section{Conclusions}

Construction industry have more chances achieving the sustainable agenda with a directed evolution towards the sustainable practices. Measuring performance has been an issue of the construction industry. The focus of construction performance has largely remained on the control of input measures such as management and resources to achieve higher performance. The contemporary frameworks and models practiced in construction industry establish the stakeholder needs and measure performance in comparison to plans. Construction labor is a major stakeholder of organizational activities, and by number the largest workforce as compared to any other business sector. The size and impact of construction labor presents a performance opportunity within itself. By steering the performance objectives to the organizational and national sustainable development construction organizations can improve social, environmental outlook of labor to generate higher profits.

The sustainable labor performance is targeted with three dimensions of sustainability (economic, social and environmental). The study indicates nine improvements domains of profits, profitability and fairness, fair wage distribution and social rights, quality of life and project experience, health, safety and wellbeing, awareness of surrounding community, construction waste, effectiveness and productivity to develop a framework to answer RQ1. Improvements in these nine areas will help construction organizations to sustain the labor performance. The nine-improvement criterion were discussed with the top management of 5 biggest Norwegian contractors. The top management of Norwegian contractors are aware of the sustainability issues with labor. They have well developed practices to measure different aspects of labor.

The knowledge is constructed form the top management of five Norwegian contractors with qualitative interviews. The selected contractors are the among the top ten Norwegian contractors in terms of number of workers and annual turnover. It seems that some measures selected from the literature have no relevance in the context of Norwegian construction industry but might hold relevance elsewhere in the world. Furthermore, the dynamics of Norwegian labor laws and strict adherence is such that it might increase the cost of construction for the contractors. However, in return it provides the contractors with a great opportunity to concentrate on better planning and achievement of plan rather than overloading them with the labor issues that are widely reported in international literature. The international contractors might have to put a lot of effort into profitability, fairness of wage distribution, social rights in the company, quality of life and wellbeing. Whereas as these issues with labor are regularized to a higher degree in Norwegian society.

Most of the dimensions to achieve improve and sustain labor performance of the contractors are covered and followed up by the Norwegian contractors. However, a dash board is missing that can aggregate and reflect the labor results. The study further suggests a 45 improvement measures inspired from the literature for evaluating SLP of construction contractors to reach RQ3. The measures are suggested with intent to promote the sustainable growth culture in the construction labor and motivate construction contractor's improvement strategies for contribution towards national sustainable growth. 
The suggested measures are divided in the levels of strategic, tactical and operational measures, which provide a unique measurement perspective to construction contractor's labor performance keeping the construction contractors aligned with the goal of national sustainable growth. The strategic improvement measures require commitment from the higher management of construction organizations. The economic measures map and objectify profits, profitability and productivity issues. The social measures inquire the quality of life, health, safety, wellbeing and social rights from labor. Whereas environmental measures asses what labor stimulate the labor towards the missed opportunities towards reducing environmental impacts such as carbon emissions to mitigate the global challenge of climate change and working effectively at the project sites. Therefore, to catalyze improvements in environmental measures, it is intended to increase the labor's environmental awareness.

It is recognized that the research has limitations in terms of number of interviews conducted to produce research findings. This is due to the challenges associated with the engagement of senior management in very busy and top Norwegian contracting companies. Researchers had very limited control over this issue. However, insights provided by the current interviewees are valuable in this study and future research needs to carry out more interviews with both senior and middle management to gain both strategic and operational perspective of improvement measures for sustainable labor performance.

\section{References}

AHMAD, S.B.S., MAZHAR, M.U., BRULAND, A., ANDERSEN, B.S., LANGLO, J.A. and TORP, O., 2018. Labour productivity statistics: a reality check for the Norwegian construction industry. International Journal of Construction Management, pp.1-14.

ABDUL KADIR, M. R., LEE, W. P., JAAFAR, M. S., SAPUAN, S. M. \& ALI, A. A. A. 2005. Factors affecting construction labour productivity for Malaysian residential projects. Structural Survey, 23, 42-54.

BASSIONI, H. A., PRICE, A. D. \& HASSAN, T. M. 2004. Performance measurement in construction. Journal of management in engineering, 20, 42-50.

BEATHAM, S. M., ANUMBA, C. J., THORPE, A. \& HEDGES, I. W. 2004. KPI's- a critical appraisal of their use in construction. Benchmarking: An international Journal, 11, 93-117.

BUZBY, C. M., GERSTENFELD, A., VOSS, L. E. \& ZENG, A. Z. 2002. Using lean principles to streamline the quotation process: a case study. Industrial Management \& Data Systems, 102, 513-520.

CHARMAZ, K. 2006. Constructing grounded theory: A practical guide through qualitative research. SagePublications Ltd, London.

CHEUNG, S. O., SUEN, H. C. \& CHEUNG, K. K. 2004. PPMS: a web-based construction project performance monitoring system. Automation in construction, 13, 361-376.

CRESWELL, J. W., PLANO CLARK, V. L., GUTMANN, M. L. \& HANSON, W. E. 2003. Advanced mixed methods research designs. Handbook of mixed methods in social and behavioral research, 209, 240.

CROSS, K. F. \& LYNCH, R. L. 1988. The "SMART" way to define and sustain success. Global Business and Organizational Excellence, 8, 23-33.

DAI, J. \& GOODRUM, P. M. 2011a. Differences in perspectives regarding labor productivity between spanish-and english-speaking craft workers. Journal of Construction Engineering and Management, 137, 689-697.

DAI, J. \& GOODRUM, P. M. Generational difference in craft workers' perceptions of the factors affecting their labour productivity. Annual Conference of the Canadian Society for Civil Engineering 2011, CSCE 2011, 2011 b Ottawa, ON. 2050-2060.

DAI, J. \& GOODRUM, P. M. 2012. Generational differences on craft workers' perceptions of the factors affecting labour productivity. Canadian Journal of Civil Engineering, 39, 1018-1026.

DAI, J., GOODRUM, P. M. \& MALONEY, W. F. 2007. Analysis of craft workers' and foremen's perceptions of the factors affecting construction labour productivity. Construction Management and Economics, 25, 1139-1152.

DAI, J., GOODRUM, P. M., MALONEY, W. F. \& SRINIVASAN, C. 2009. Latent structures of the factors affecting construction labor productivity. Journal of Construction Engineering and Management, 135, 397-406. 
DOLAGE, D. \& CHAN, P. 2013. Productivity in Construction-A Critical Review of Research. Engineer: Journal of the Institution of Engineers, Sri Lanka, 46.

DURDYEV, S. \& MBACHU, J. 2011. On-site labour productivity of New Zealand construction industry: Key constraints and improvement measures. Australasian Journal of Construction Economics and Building, 11, 18-33.

EGAN, J. 1998. Rethinking Construction. London: Dept. of the Environment, Transport and Regions.

EL-MASHALEH, M. S., EDWARD MINCHIN JR, R. \& O'BRIEN, W. J. 2007. Management of construction firm performance using benchmarking. Journal of Management in Engineering, 23, $10-17$.

ELKINGTON, J. 1994. Towards the sustainable corporation: Win-win-win business strategies for sustainable development. California management review, 36, 90-100.

ENSHASSI, A., MOHAMED, S., MUSTAFA, Z. A. \& MAYER, P. E. 2007. Factors affecting labour productivity in building projects in the Gaza strip. Journal of Civil Engineering and Management, 13, 245-254.

FLEURBAEY, M. \& BLANCHET, D. 2013. Beyond GDP: Measuring welfare and assessing sustainability, Oxford University Press.

GARVIN, D. A. 1994. Building a learning organization. BUSINESS CREDIT-NEW YORK-, 96, 19-19.

GHODDOUSI, P., POORAFSHAR, O., CHILESHE, N. \& HOSSEINI, M. R. 2015. Labour productivity in Iranian construction projects perceptions of chief executive officers. International Journal of Productivity and Performance Management, 64, 811-830.

GILES, T., KING, L. \& DE LACEY, S. 2013. The timing of the literature review in grounded theory research: an open mind versus an empty head. Advances in Nursing Science, 36, E29-E40.

HALACHMI, A. 2002. Performance measurement and government productivity. Work Study, 51, 6373.

HALL, T. J. 2011. The triple bottom line: what is it and how does it work? Indiana business review, $86,4$.

HELLIWELL, J. F., HUANG, H. \& WANG, S. 2017. The Social Foundations of World Happiness. WORLD HAPPINESS REPORT 2017, 8.

HORTA, I. M., CAMANHO, A. S. \& DA COSTA, J. M. 2009. Performance assessment of construction companies integrating key performance indicators and data envelopment analysis. Journal of Construction Engineering and Management, 136, 581-594.

HORTA, I. M., CAMANHO, A. S. \& DA COSTA, J. M. 2012. Performance assessment of construction companies: A study of factors promoting financial soundness and innovation in the industry. International Journal of Production Economics, 137, 84-93.

JARKAS, A. M. 2015. Factors influencing labour productivity in Bahrain's construction industry. International Journal of Construction Management, 15, 94-108.

JARKAS, A. M., AL BALUSHI, R. A. \& RAVEENDRANATH, P. K. 2015. Determinants of construction labour productivity in Oman. International Journal of Construction Management, $15,332-344$.

JARKAS, A. M. \& BITAR, C. G. 2011. Factors affecting construction labor productivity in Kuwait. Journal of Construction Engineering and Management, 138, 811-820.

JARKAS, A. M. \& YOUNES, J. H. 2014. Principle factors contributing to construction delays in the State of Qatar. International Journal of Construction Project Management, 6, 39.

KAPŁAN, R. \& NORTON, D. 1992. The Balanced Scorecard-Measures That Drive Performance. Harvard Business Review, 1.

KAPLAN, R. S. \& NORTAN, D. P. 1992. The Balanced Scorecard-Measures That Drive Performances. Harvard business review, 70, 71-79.

KEEGAN, D. P., EILER, R. G. \& JONES, C. R. 1989. Are your performance measures obsolete? Strategic Finance, 70, 45.

KHAHRO, S. H., ALI, T. H., MEMON, N. A. \& MEMON, Z. A. 2016. Improving labour productivity: An attribute case study of building sector projects in Pakistan. International Journal of Applied Engineering Research, 11, 11121-11125.

KIM, S.-Y. \& HUYNH, T.-A. 2008. Improving project management performance of large contractors using benchmarking approach. International Journal of Project Management, 26, 758-769. 
KOSKELA, L. 2000. An exploration towards a production theory and its application to construction, VTT Technical Research Centre of Finland.

LAM, S. \& TANG, C. 2003. Motivation of survey employees in construction projects. Journal of geospatial engineering, 5, 61-66.

LATHAM, M. 1994. Constructing the team. London: HMSO.

LEMPERT, L. B. 2007. Asking Questions of the Data: Memo Writing in the Grounded. The Sage handbook of grounded theory, 245-264.

MISNI, F. and LEE, L.S., 2017. A review on strategic, tactical and operational decision planning in reverse logistics of green supply chain network design. Journal of Computer and Communications, 5(08), p.83.

MAHAMID, I. 2013. Contractors perspective toward factors affecting labor productivity in building construction. Engineering, Construction and Architectural Management, 20, 446-460.

MARCH, J. G. \& SUTTON, R. I. 1997. Crossroads-organizational performance as a dependent variable. Organization science, 8, 698-706.

MASKELL, B. H. 1991. Performance measurement for world class manufacturing: A model for American companies, CRC press.

MCDONOUGH, W. \& BRAUNGART, M. 2002. Design for the triple top line: new tools for sustainable commerce. Corporate Environmental Strategy, 9, 251-258.

MCNALLY, H. E. \& HAVERS, J. A. 1967. Labor productivity in the construction industry. Journal of the Construction Division, 93, 1-12.

MCTAGUE, B. \& JERGEAS, G. 2002. Productivity Improvements on Alberta Major Construction Projects: Phase I-Back to Basics, Alberta economic development.

MICHELI, P. \& MARI, L. 2014. The theory and practice of performance measurement. Management accounting research, 25, 147-156.

NAOUM, S. G. 2016. Factors influencing labor productivity on construction sites: A state-of-the-art literature review and a survey. International Journal of Productivity and Performance Management, 65, 401-421.

NAVON, R. \& SACKS, R. 2007. Assessing research issues in automated project performance control (APPC). Automation in Construction, 16, 474-484.

NEELY, A. \& ADAMS, C. 2001. The performance prism perspective. Journal of cost management, $15,7-15$.

NEELY, A. \& BOURNE, M. 2000. Why measurement initiatives fail. Measuring business excellence, $4,3-7$.

NEELY, A., GREGORY, M. \& PLATTS, K. 2005. Performance measurement system design: A literature review and research agenda. International journal of operations \& production management, 25, 1228-1263.

NORWAY, S. 2018. Construction, structural business statistics [Online]. Norway. Available: https://www.ssb.no/en/bygg-bolig-og-eiendom/statistikker/stbygganl [Accessed 15.02.2018].

OECD 2010. Construction Industry. OECD Journal: Competition Law and Policy.

OECD 2017a. OECD Compendium of Productivity Indicators 2017, Paris, OECD Publishing.

OECD. 2017b. Organization For Economic Co-operation and Development [Online]. Available: https://data.oecd.org/natincome/value-added-by-activity.htm [Accessed 1.06.2017 2017].

PANAS, A. \& PANTOUVAKIS, J. 2010. Evaluating research methodology in construction productivity studies. The Built \& Human Environment Review, 3, 63-85.

PILATERIS, P. \& MCCABE, B. 2003. Contractor financial evaluation model (CFEM). Canadian Journal of Civil Engineering, 30, 487-499.

PILLAI, A. S., JOSHI, A. \& RAO, K. S. 2002. Performance measurement of R\&D projects in a multiproject, concurrent engineering environment. International Journal of Project Management, 20, 165-177.

POPPER, K. 1934. The Logic of Scientific Discovery (London: Hutchinson, 1959). However many white swans we count, Popper argues, we cannot with certainty say that all swans are white. But if we see one black swan, we can confidently say that "not all swans are white.

RANKIN, J., FAYEK, A. R., MEADE, G., HAAS, C. \& MANSEAU, A. 2008. Initial metrics and pilot program results for measuring the performance of the Canadian construction industry. Canadian Journal of Civil Engineering, 35, 894-907. 
ROGNLIE, M. 2016. Deciphering the fall and rise in the net capital share: accumulation or scarcity? Brookings papers on economic activity, 2015, 1-69.

ROJAS, E. M. \& ARAMVAREEKUL, P. 2003. Labor productivity drivers and opportunities in the construction industry. Journal of Management in Engineering, 19, 78-82.

SAVITZ, A. 2013. The triple bottom line: how today's best-run companies are achieving economic, social and environmental success-and how you can too, John Wiley \& Sons.

SHAMAS-UR-REHMAN TOOR, S. O. 2010. Ogunlana,"Beyond the 'iron triangle': Stakeholder perception of key performance indicators (KPI) for large-scale public sector development projects". International Journal of Project Management, 28, 228-236.

SINGH, H., MOTWANI, J. \& KUMAR, A. 2000. A review and analysis of the state-of-the-art research on productivity measurement. Industrial Management \& Data Systems, 100, 234-241.

SKIBNIEWSKI, M. J. \& GHOSH, S. 2009. Determination of key performance indicators with enterprise resource planning systems in engineering construction firms. Journal of construction engineering and management.

STERN, S., WARES, A., ORZELL, S. \& O'SULLIVAN, P. 2015. Social progress index 2014 methodological report. Retrieved April, 4, 691-705.

STIGLITZ, J., SEN, A. \& FITOUSSI, J.-P. 2009. The measurement of economic performance and social progress revisited. Reflections and overview. Commission on the Measurement of Economic Performance and Social Progress, Paris.

TANGEN, S. 2005. Demystifying productivity and performance. International Journal of Productivity and performance management, 54, 34-46.

THOMAS, H. R., MALONEY, W. F., HORNER, R. M. W., SMITH, G. R., HANDA, V. K. \& SANDERS, S. R. 1990. Modeling construction labor productivity. Journal of Construction Engineering and Management, 116, 705-726.

WHITE, G. P. 1996. A survey and taxonomy of strategy-related performance measures for manufacturing. International Journal of Operations \& Production Management, 16, 42-61.

WOMACK, J. P. \& JONES, D. T. 1996. Lean Thinking, Simon and Schuster. New York.

YANG, H., YEUNG, J. F., CHAN, A. P., CHIANG, Y. \& CHAN, D. W. 2010. A critical review of performance measurement in construction. Journal of Facilities Management, 8, $269-284$. 


\section{Appendix A}

A-1. Company Information

1.1. Your company's name:

1.2. Personal Details

\begin{tabular}{|l|l|}
\hline Name & \\
\hline Position & \\
\hline Phone Number & \\
\hline e-mail address & \\
\hline
\end{tabular}

1.3. Please specify how many years of working experience you have in the construction industry. Years

1.4. How would you classify your company?

Client with in-house design capabilities

Client without in-house design capabilities

Contractor

Consultant

Sub-contractor

Designer/Contractor

Others, Specify . 


\begin{tabular}{|c|c|c|}
\hline \multicolumn{2}{|l|}{ Questions } & \multirow[t]{2}{*}{ Remarks } \\
\hline 1. I & $\begin{array}{l}\text { How do you measure labor Productivity in your company for the projects and at company } \\
\text { level? }\end{array}$ & \\
\hline 2. $\mathbf{I}$ & How do you think the labor productivity can be measured in a better way? & \\
\hline $\begin{array}{ll}\text { 3. } & \mathbf{H} \\
\text { i }\end{array}$ & $\begin{array}{l}\text { How do you currently measure the profits weather the profits from your labor have } \\
\text { improved? }\end{array}$ & \\
\hline 4. $\mathrm{F}$ & $\begin{array}{l}\text { How do you think we can measure the profits from the Labor have improved in a better } \\
\text { way? }\end{array}$ & \\
\hline 5. $\mathbf{I}$ & How do you currently measure the profitability of your Labor? & \\
\hline 6. I & How do you think we can measure the profitability of Labor in a better way? & \\
\hline 7. $\mathbf{I}$ & How do you currently measure the capacity of your Labor? & \\
\hline 8. $\mathbf{I}$ & How do you think the capacity of the Labor can be measured in a better way? & \\
\hline 9. $\mathbf{H}$ & How do you currently measure the effectiveness of Labor operations in your company? & \\
\hline 10. $\mathbf{F}$ & How do you think the effectiveness of Labor operations can be measured in a better way? & \\
\hline 11. $\mathbf{F}$ & $\begin{array}{l}\text { How do you currently measure that your labor have fair wage distribution and social } \\
\text { rights in your company? }\end{array}$ & \\
\hline 12. $\mathrm{F}$ & $\begin{array}{l}\text { How do you think fair wage distribution and social rights can be measured in a better } \\
\text { way? }\end{array}$ & \\
\hline 13. I & $\begin{array}{l}\text { How do you currently measure the quality of life and project experience of your Labor in } \\
\text { your company? }\end{array}$ & \\
\hline 14. I & $\begin{array}{l}\text { How do you think the quality of life and project experience of your Labor can be measured } \\
\text { in a better way? }\end{array}$ & \\
\hline 15. $\mathbf{F}$ & How do you currently measure the health, safety and wellbeing of your Labor? & \\
\hline 16. I & $\begin{array}{l}\text { How do you think the health, safety and wellbeing of your Labor can be measured in a } \\
\text { better way? }\end{array}$ & \\
\hline 17. I & $\begin{array}{l}\text { How do you currently measure that your Labor has respect for the surrounding } \\
\text { community at the project sites? }\end{array}$ & \\
\hline 18. I & $\begin{array}{l}\text { How do you think the labor's respect of surrounding community and nature can be } \\
\text { measured in a better way? }\end{array}$ & \\
\hline 19. $\mathrm{F}$ & $\begin{array}{l}\text { How do you think we can create a better system to improve and sustain higher labor } \\
\text { performance and productivity? }\end{array}$ & \\
\hline 20. V & Would you like to add anything to the context of the interview? & \\
\hline
\end{tabular}




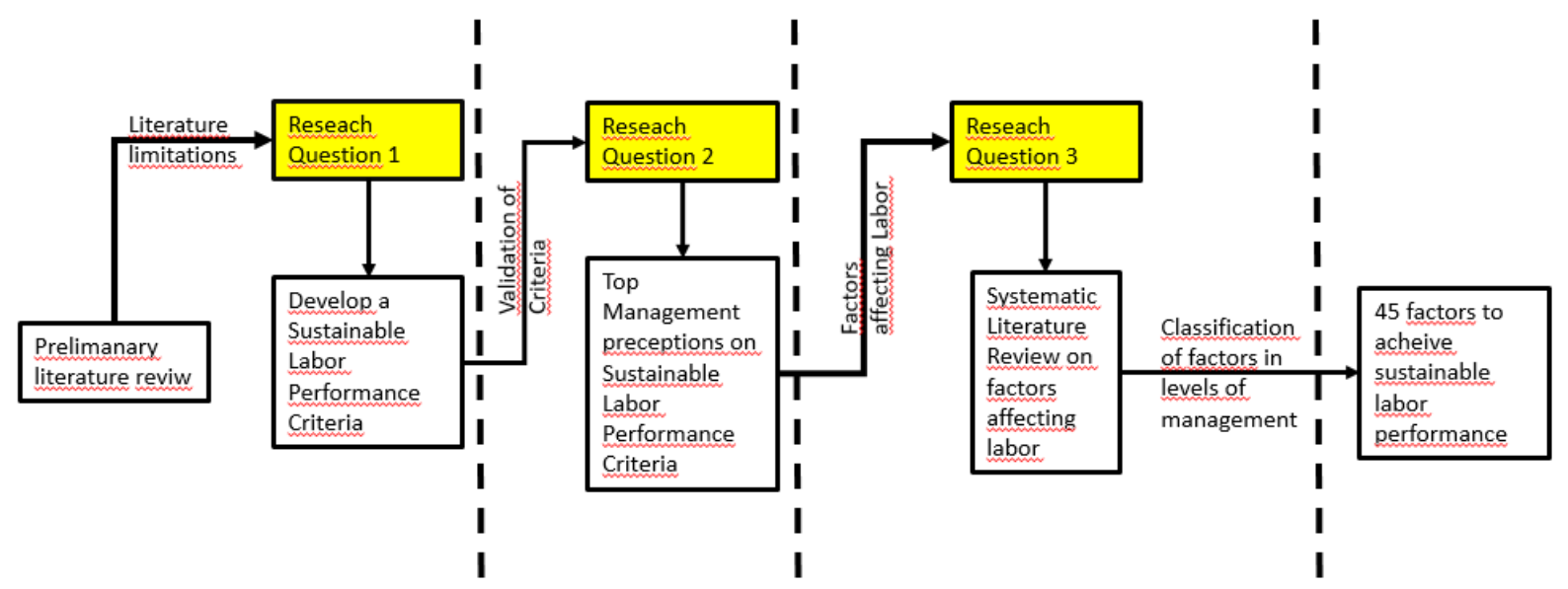

Figure 1: Research Flow Diagram

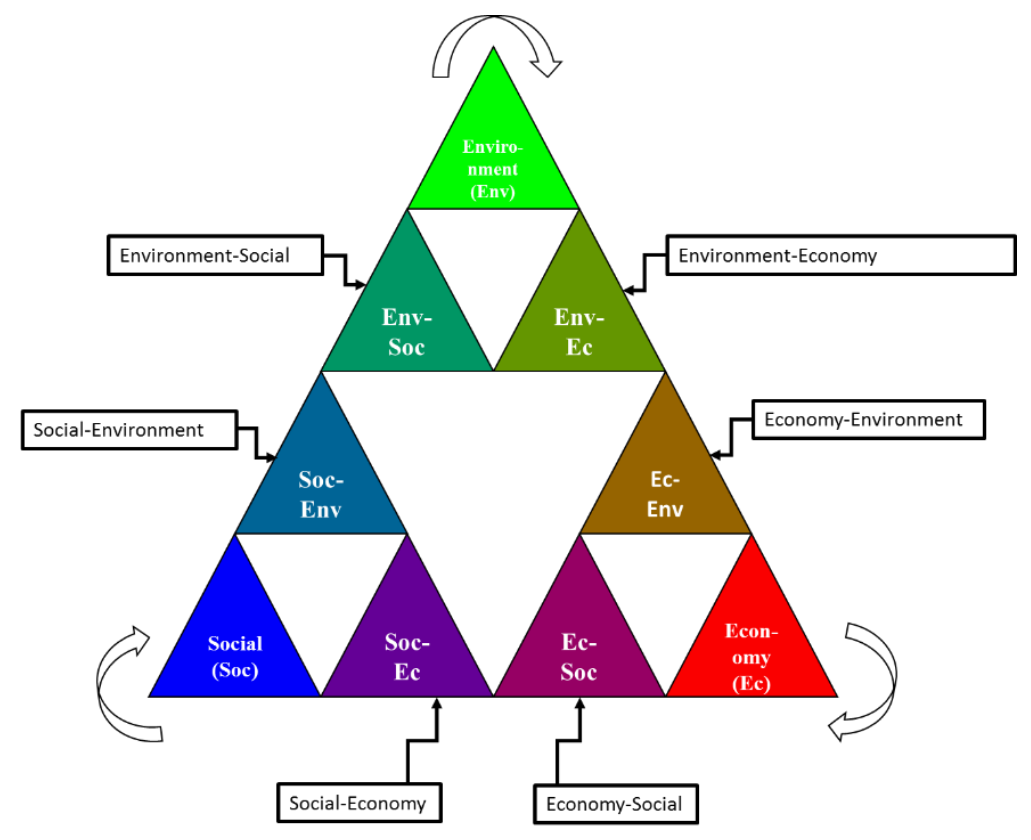

Figure 2: Fractral Triangle for sustainable labor performance (inspired from McDonough and Braungart, 2002) 
Table 1: Details of the interview participants and construction contractors

\begin{tabular}{|c|c|c|c|c|}
\hline \multirow{2}{*}{$\begin{array}{l}\text { Com- } \\
\text { pany }\end{array}$} & \multicolumn{2}{|l|}{ Representatives } & \multirow{2}{*}{$\begin{array}{l}\text { Number of } \\
\text { Employees }\end{array}$} & \multirow{2}{*}{$\begin{array}{l}\text { Turnover } \\
\text { (million } \\
\text { NOK) }\end{array}$} \\
\hline & Job Position & $\begin{array}{l}\text { Job } \\
\text { experience }\end{array}$ & & \\
\hline 1 & Chief Executive Officer (CEO) & 22 years & 2049 & 8501.3 \\
\hline 2 & Director Strategy and Development & 37 years & 7164 & 28613 \\
\hline 3 & Regional Manager East & 38 years & 380 & 3266.1 \\
\hline \multirow[t]{2}{*}{4} & Portfolio Manager & 41 years & \multirow[t]{2}{*}{2530} & \multirow[t]{2}{*}{7544} \\
\hline & Manager Sustainability and Environment & 5 years & & \\
\hline 5 & $\begin{array}{l}\text { Vice President Project and Risk } \\
\text { Management }\end{array}$ & & 3730 & 12295 \\
\hline \multicolumn{3}{|c|}{ TOTAL } & 15853 & 60219.4 \\
\hline
\end{tabular}




\begin{tabular}{|c|c|c|c|}
\hline 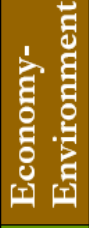 & 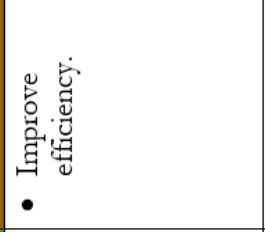 & 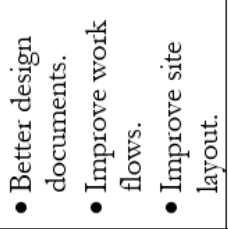 & 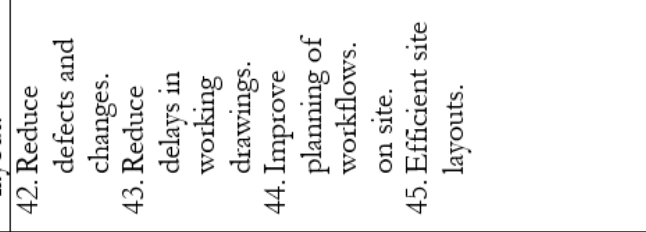 \\
\hline 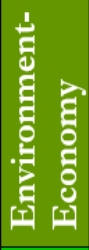 & 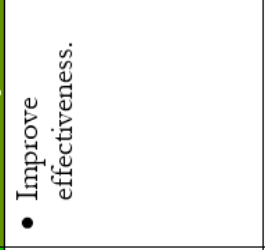 & 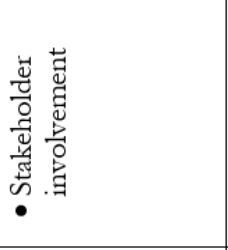 & 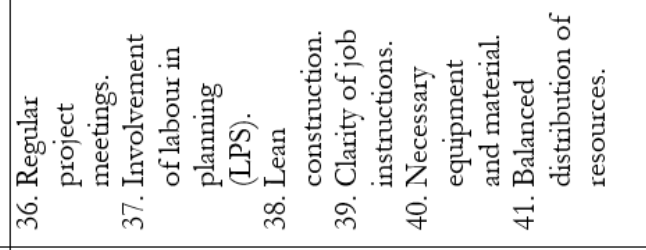 \\
\hline 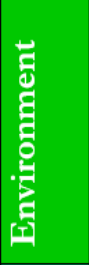 & 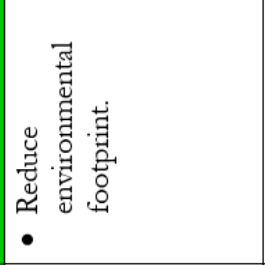 & 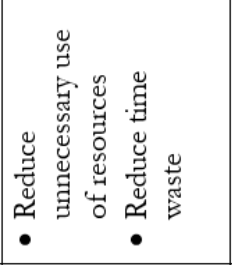 & 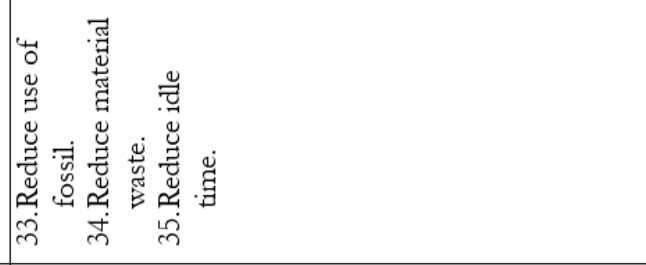 \\
\hline 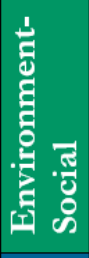 & 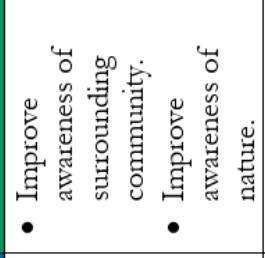 & 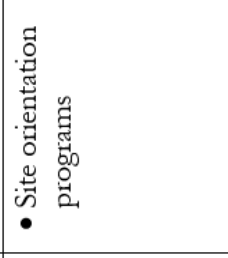 & 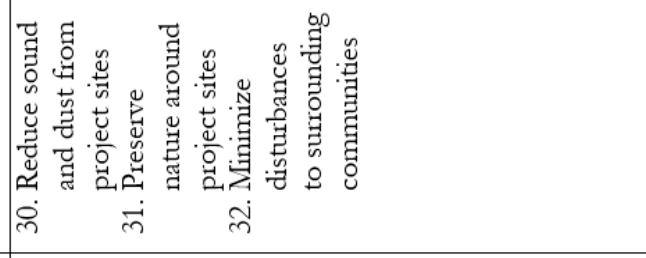 \\
\hline 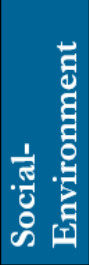 & 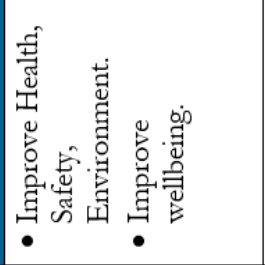 & 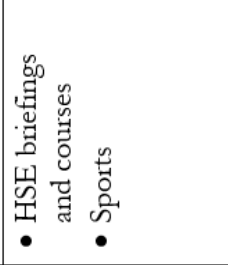 & 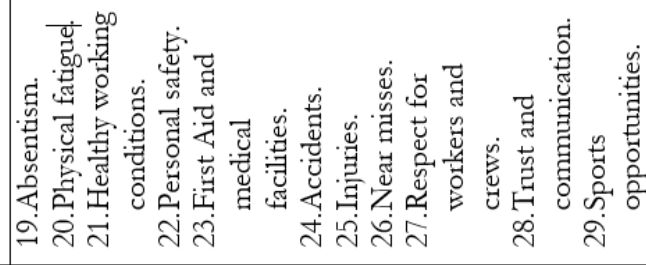 \\
\hline 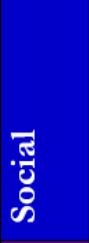 & 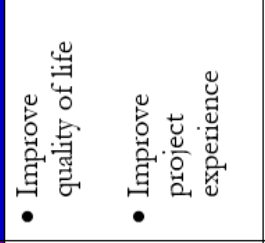 & 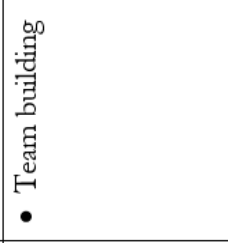 & 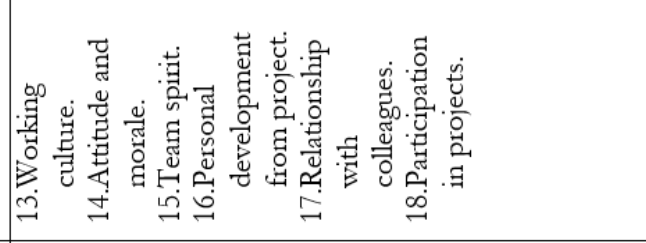 \\
\hline 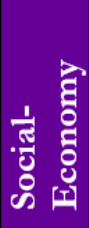 & 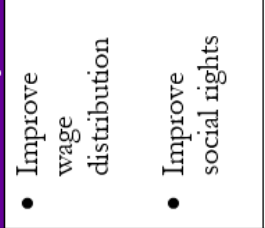 & 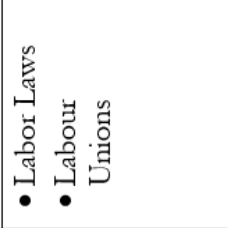 & 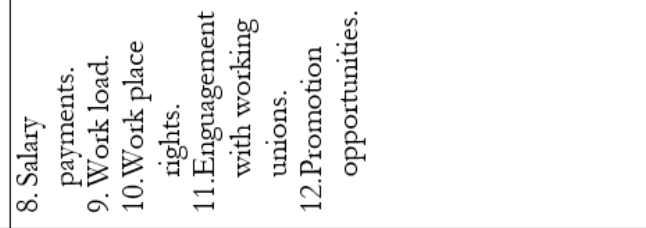 \\
\hline 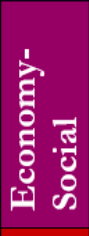 & 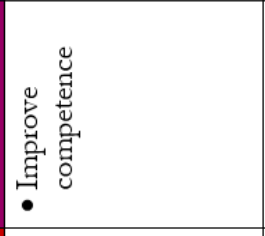 & 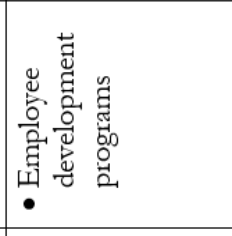 & 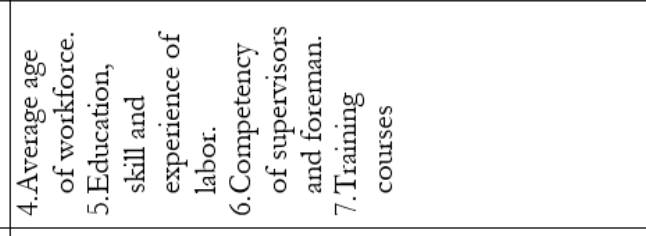 \\
\hline 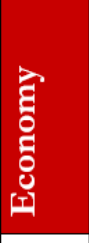 & 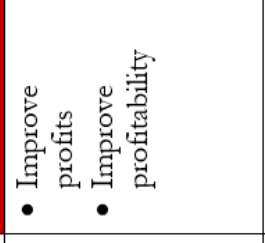 & 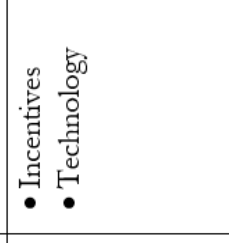 & 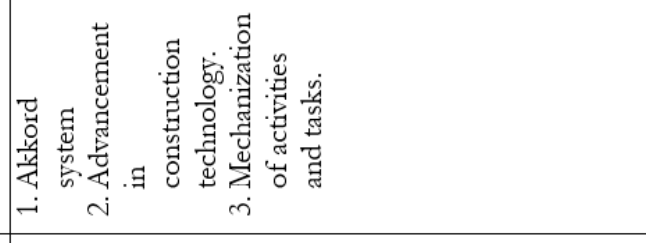 \\
\hline 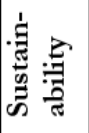 & 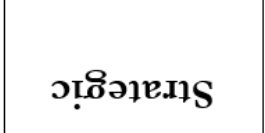 & 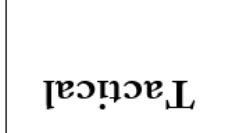 & 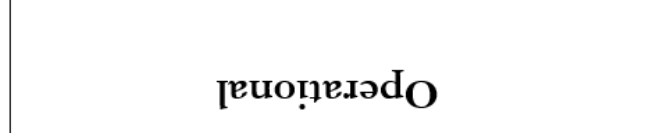 \\
\hline
\end{tabular}

